\title{
Volatility Transmission between Stock and Foreign Exchange Markets: Evidence from Nigeria
}

\author{
Emenike Kalu O. ${ }^{1}$ \\ Department of Banking and Finance \\ Rhema University, Aba, Abia State, Nigeria \\ Email: emenikekaluonwukwe@yahoo.com
}

Received: 6 December 2013 / Revised: 13 January 2014 / Accepted: 20 January 2014 / Published online: 19 May 2014

\begin{abstract}
The direction of volatility transmission between stock and foreign exchange markets is important for hedging strategy, portfolio management and financial market regulation. This paper examines volatility transmission between stock and foreign exchange markets by applying the multivariate GARCH model in the BEKK framework to Nigerian stock returns and the Naira/USD exchange rate data from January 1996 to March 2013. Results of the empirical analysis show evidence of volatility clustering in both stock and foreign exchange markets. The results also show bidirectional shock transmission between stock and foreign exchange markets, suggesting that information flow in the foreign exchange market impact the stock market and vice versa. Finally, the results show evidence of a uni-directional volatility transmission from the foreign exchange market to the stock market. The implication is for investors vigilantly to monitor and dissect all information in the two markets as part of their investment strategy.
\end{abstract}

JEL Classification: G11, C32

Keywords: stock market, foreign exchange market, volatility transmission, BEKK-GARCH model

\section{INTRODUCTION}

There has been a good number of empirical studies that analyse volatility transmission ${ }^{2}$ across countries, financial markets and sectors of financial markets (see for example, Hamao, Masulis and Ng 1990; Karolyi, 1995; Malik and Ewing, 2009; Hoon and Yoon, 2013). Most of these earlier studies were motivated partly in response to increasing integration of international financial markets resulting from advancement in information and communication technology (ICT). Increasing integration of financial markets leads to price co-movement, shocks and volatility transmission between markets. A shock in one financial market may lead to shocks in other financial markets as apparently illustrated by the global financial crises which started in United States and spread to almost all world economies.

The effect of financial market linkages on volatility transmission is an important issue that investors need to consider before making investment decision, and policy-makers also

Corresponding author: Emenike Kalu O., Department of Banking and Finance, Rhema University, Aba, Abia State, Nigeria; e-mail: emenikekaluonwukwe@yahoo.com.

2 Existence of volatility transmission implies that one large shock increases the volatilities not only in its own asset or market but also in other assets or markets. 
need to factor it into policy making. This is because volatility is an unattractive feature that has adverse implications for decisions pertaining to the effective allocation of resources and investment (Nnachi, 2008). For instance, volatility makes investors more averse to holding stocks and investors, in turn, demand a higher risk premium in order to insure against the increased uncertainty (Emenike, 2010). Knowledge of volatility transmission between financial markets is, therefore, very important for hedging strategies, risk management and financial market regulation.

Malik and Ewing (2009) identify cointegration and time-path of volatility as the two main lines of research in the context of transmission of shocks among financial time series and analysis of volatility. While co-integration is adopted to study co-movements between financial markets over long time periods, time-path of volatility concentrates on volatility behaviour in a market and how the volatility of one market affects other markets. Despite differences in methodology, authors generally find evidence of co-movement between financial markets across countries and inter-dependence within markets and sectors in the same country (see for example, Engel, Ito and Lin 1990; Malik and Ewing, 2009; Turkyilmaz and Balibey, 2013).

These earlier studies adopted a wide range of methodologies to evaluate volatility transmission across financial markets. Some of the studies apply uni-variate ARCH family models ${ }^{3}$ to estimate volatility transmission in two stages (see Engel et al. 1990; Hamao et al. 1990; Okpara and Odionye 2012). Studies applying uni-variate models normally introduce the conditional variance of a variable as an explanatory variable in another conditional variance model. This method however ignores the possibility of having causality between volatilities in both directions and does not exploit the co-variance between both series (Felipe and Diranzo, 2012). As a result of these shortcomings, other studies adopt mult-ivariate GARCH models as a more effective way of examining interactions among volatilities of different financial markets or sectors of the same financial market. Some examples of multi-variate GARCH models commonly used in the literature include vector multi-variate GARCH $(\mathrm{VECH})$ and Diagonal VECH representations of Bollerslev, Engle and Wooldidge (1988), BEKK representation (an acronym formed form the authors of the paper), Baba, Engle, Kraft and Kroner (1990) and Engle and Kroner (1995), constant conditional Correlation (CCC) of Bollerslev (1990), and so on.

While literature on the impact of exchange rate on stock market volatility ${ }^{4}$ and a separate literature on volatility spillover in a uni-variate EGARCH framework ${ }^{5}$ exist, there is, to be best of the author's knowledge, no literature on the interactions between volatilities of the two financial markets in Nigeria. Moreover, as Ghosh (2012) notes, in the presence of a large spillover effect, a shock in one of the markets could have a destabilizing impact on the other market. This suggests that the relationship between stock and foreign exchange markets may be used in predicting the future trends for each other, thereby helping to clarify how information is transmitted across financial markets in Nigeria.

Again, the linkage between volatility of stock and foreign exchange markets is important for foreign exchange traders, professional investors and regulators in Nigeria because of the import-dependent and the mono-production nature of the economy. The majority of the goods and services consumed in Nigeria are imported and the major export product of Nigeria, crude oil, is priced in USD. As Kim (2003) observes, the continuing increases in the world trade and capital movements have made the exchange rates the main determinants of business profitability and equity prices. The stock market, on the other hand, plays a vital role in stimulating industrial and

\footnotetext{
The ARCH model was introduced by Engle (1982) and generalised by Bollerslev (1986). Nelson (1991) introduced a number of refinements on the uni-variate GARCH model in using exponential GARCH to detect asymmetric volatility in the stock return series. The first of these refinements was to model the log of the variance, rather than the level. This ensures that the estimated conditional variance is strictly positive, thus non-negativity constraints of the ARCH and GARCH models are not necessary. The second is the inclusion of asymmetry parameter to respond to positive and negative shocks.

Yaya and Shittu (2010) provide evidence to show that exchange rate has positive and significant influence on the volatility of stock returns in

Okpara and Odionye (2012) find that volatility spillover to stock prices from the exchange rates in Nigeria.
} Nigeria. 
economic growth. More importantly, from the financial stability perspective, shock and volatility transmission among stock and foreign exchange markets warrant closer scrutiny.

Accordingly, this paper evaluates the nature of volatility transmission between the Nigerian stock and foreign exchange markets by exploring the time path of the volatility of both markets using BEKK specification of multi-variate GARCH. The intensity and the direction of volatility transmission among these two markets hold invaluable information for the stock market investors (domestic and international), foreign exchange traders, financial market regulators and academics. Section 2 contains the theoretical basis of the study and previous empirical findings. Section 3 describes the methodology and data for analysis. Section 4 presents empirical results, and section 5 presents concluding remarks.

\section{THEORETICAL BASIS AND PREVIOUS EMPIRICAL FINDINGS}

The theoretical basis for the study of the linkage between foreign exchange and stock markets are the 'flow-oriented' model of Dornbusch and Fisher, (1980) and the 'stock-oriented' models of Branson, (1983), Frankel (1983) and Branson and Henderson (1985). The flow-oriented model of exchange rates postulates that changes in foreign exchange rates alter the international competitiveness of a firm as well as the balance of trade position. Local currency depreciation thus acts to strengthen the competitiveness of domestic firms as their exports will be cheaper in international trade. Hence, the flow-oriented model suggests a positive relation between stock prices and foreign exchange rates. The stock-oriented models of exchange rates, on the other hand, propose that foreign exchange rate movements function to balance the demand and supply of domestic and foreign financial assets. Thus, an increase in stock returns induces investors to demand more domestic financial assets and thereby causes an appreciation in the domestic currency. The appreciation of the domestic currency attracts more foreign capital and investments into the domestic market, which then leads to further currency appreciation. Consequently, the stock-oriented models suggest a negative linkage between foreign exchange rates and stock prices.

The flow-oriented and stock oriented theories, therefore, suggest that these fund-flows may create shock and volatility transmission between stock and foreign exchange markets.

The early empirical studies of return and volatility transmission concentrated on interdependence between different assets or markets across countries. Engle et al. (1990), for example, apply univariate GARCH model $^{6}$ to examine volatility spillover across the Japanese and American foreign exchange markets. They find the presence of intra-day volatility spillovers from one foreign exchange market to the other. In like manner, Hamao et al. (1990) analyse the short-run interdependence of prices and price volatility across the London, New York and Tokyo stock markets in the pre-October period. They show evidence of price volatility spillover from New York to London, from New York to Tokyo and from London to Tokyo but not in other directions. Some other studies that find evidence of volatility spillover between countries include Hong (2001), Bhar and Hamori, (2003), Inagaki (2007) and so on.

The wealth of empirical literature on return and volatility transmission supports the existence of return and volatility transmission between the stock and foreign exchange markets, but the direction of transmission has been mixed. Kanas (2000) examines volatility spillovers between stock returns and exchange rate changes in six industrialized countries, namely, the US, the UK, Japan, Germany, France, and Canada. He finds evidence of spillovers from stock market returns

The uni-variate GARCH model has two major shortcomings. First, it ignores the possibility of having causality between volatilities in both directions. Secondly, it does not explore the information contained in covariance matrix of residuals of the series under study (Hurditt, 2004; Felipe and Diranzo, 2006). 
to exchange rate changes for all countries except Germany. On the other hand, the volatility spillovers from exchange rate changes to stock returns are completely insignificant.

Similarly, Yang and Doong (2004) explored the nature of the mean and volatility transmission mechanism between stock and foreign exchange markets in the G-7 using a vector autoregression multi-variate EGARCH model. Their empirical evidence shows an asymmetric volatility spillover effect and that stock price movements will impact on future exchange rate movements, but exchange rate changes have less direct effect on future stock returns.

Morales and O'Donnell (2007) examine the volatility spillovers between stock market returns and exchange rate changes for Spain, Portugal, and Italy using an EGARCH model. They find no significant volatility spillovers from stock returns to exchange rates or vice-versa prior to the introduction of the Euro. However, with the introduction of the Euro, there were significant volatility spillovers from stock returns to exchange rates in all countries for all currencies, with the exception of Portugal in the more recent (2002-2006) period. Mishra, Swain and Malhotra (2007), explore volatility spillovers between the Indian stock and foreign exchange markets. Their results indicate evidence of a bi-directional volatility spillover between the Indian stock market and the foreign exchange market with the exception of S\&P CNX NIFTY and S\&P CNX 500. They conclude that the markets are integrated with each other.

Choi, Tian and $\mathrm{Fu}(2009)$ in their study of the volatility spillover between New Zealand stock market returns and changes exchange rate using multivariate EGARCH model, find amongst other, evidence of bidirectional volatility spillovers between the NZ stock market returns and NZD/USD exchange rate in the full sample period and in the pre-Asian financial crisis sample period.

In contrast to the findings of Choi et al., Fedorova and Saleem (2010) find evidence of direct linkages between equity markets in terms of both returns and volatility, as well as in the currency markets. They also show uni-directional volatility spillovers from currency to stock markets in Eastern European markets and in Russia using a bi-variate GARCH-BEKK model. They conclude that there is integration of Eastern European markets within the region and with Russia as well.

Arifin and Syahruddin (2011) investigate volatility spillover effects between stock market returns and exchange rate changes within the same economy in the ASEAN-5 countries, during the Asian crisis and the sub-prime crisis, using a bi-variate VAR(1)-GARCH(1.1) model with BEKK representation. They provide evidence to show that exchange rate fluctuations have strong influences on the volatility of stock market.

Okpara and Odionye (2012), in their study, appraise the direction of volatility spillover between stock prices and exchange rate in Nigeria using a uni-variate EGARCH model. They show uni-directional volatility spillover running from exchange rate to stock prices. Hoon and Yoon (2012) investigate volatility spillover between stock prices and exchange rates in Asian financial markets using a bi-variate GARCH model. They find evidence of bi-directional volatility spillover between two markets in Asia.

In a recent study, Turkyilmaz and Balibey, (2013) examine the relationship between interest rate, exchange rate and stock price using the BEKK-MGARCH approach ${ }^{7}$. They conclude that there is significant transmission of shocks and volatility among the three variables. Hoon and Yoon (2013), revisit the price returns and volatility linkages between the foreign exchange and stock markets in Korea, using the co-integration test and bi-variate GJR-GARCH (1.1) model based on the BEKK approach. Their results reveal, amongst other things, evidence that a unidirectional volatility spillover exists from the stock market to the foreign exchange market. They also show that there is no evidence of volatility spillover effect in the pre-crisis, but an evidence of uni-directional volatility spillover effect from the foreign exchange market to the stock market

Multi-variate GARCH models explicitly account for the shortcomings of uni-variate approach. 
in the post-crisis period. They conclude that financial crisis improves linkages between the two markets.

In the light of the brief review of the volatility transmission literature, evidence-based knowledge of co-variance between financial markets, sectors or assets is of the essence in finance, as many problems in financial practice, such as efficient portfolio management, hedging strategies and financial market regulation, require multi-variate volatility measures.

\section{METHODOLOGY AND DATA FOR ANALYSIS}

\subsection{Methodology}

The BEKK representation of a multi-variate GARCH model outlined in Baba et al. (1990) and Engle and Kroner (1995) is adopted to investigate volatility transmission between stock and foreign exchange markets in Nigeria. The BEKK model presents a natural way to estimate the interaction within the conditional mean and conditional variance of two or more series because of its capability to detect volatility transmission among the series, as well as persistence of volatility within each series.

The first step in the multi-variate GARCH methodology is to specify the mean equation. Thus, the mean equation for return series is specified as follows:

$$
\begin{aligned}
& R_{t}=\mu_{i}+\theta R_{i, t-i}+\varepsilon_{t} \\
& \varepsilon_{t}=H_{t}^{1 / 2} \eta_{t}
\end{aligned}
$$

where: $R_{t}=\left(R_{t}^{S}, R_{t}^{E}\right)^{\prime}$ is a vector of returns of the stock and foreign exchange markets respectively, $\theta$ refers to a $2 \times 2$ matrix of coefficients, $\varepsilon_{t}=\left(\varepsilon_{t}^{S}, \varepsilon_{t}^{E}\right)^{\prime}$ is the vector of error terms of conditional mean equation for stock and foreign exchange markets returns respectively. $\eta_{t}=\left(\eta_{t}^{S}, \eta_{t}^{E}\right)$ is

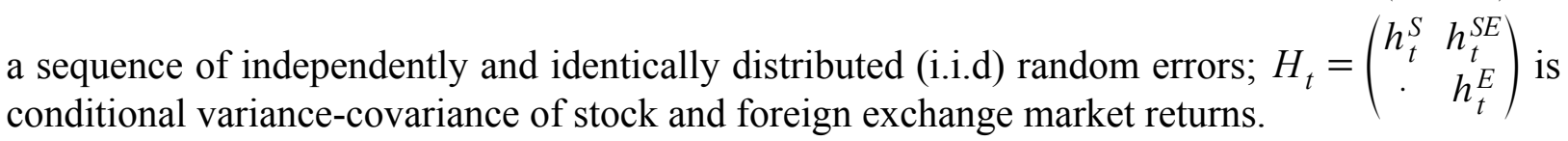

The next step is to specify the conditional variance-covariance equation. Thus, the BEKK representation of multi-variate GARCH (1.1) model is given by:

$$
H_{t}=C C^{\prime}+A \varepsilon_{t-1} \varepsilon_{t-1}^{\prime} A^{\prime}+B H_{t-1} B^{\prime}
$$

where: $H_{t}$ is the conditional variance matrix. $C, A$, and $B$ are parameter matrices. $C$ is a $2 \times 2$ lower triangular matrix, $A$ is $2 \times 2$ square matrix that shows how conditional variances correlate with past squared errors, and $B$ is $2 \times 2$ square matrix that measures the effect of past conditional variances on the current conditional variances and the degree of persistence in the volatility of the markets. The parameter matrices can be represented as follows:

$$
\begin{aligned}
{\left[\begin{array}{cc}
h_{11, t} & h_{12, t} \\
\cdot & h_{22, t}
\end{array}\right]=} & {\left[\begin{array}{cc}
c_{11}^{0} & c_{12}^{0} \\
0 & c_{22}^{0}
\end{array}\right]^{\prime}\left[\begin{array}{cc}
c_{11}^{0} & c_{12}^{0} \\
0 & c_{22}^{0}
\end{array}\right]+\left[\begin{array}{ll}
a_{11}^{*} & a_{12}^{*} \\
a_{21}^{*} & a_{22}^{*}
\end{array}\right]^{\prime}\left[\begin{array}{cc}
\varepsilon_{1, t-1}^{2} & \varepsilon_{1, t-1} \varepsilon_{2, t-1} \\
\varepsilon_{1, t-1} \varepsilon_{2, t-1} & \varepsilon_{2, t-1}^{2}
\end{array}\right]\left[\begin{array}{ll}
a_{11}^{*} & a_{12}^{*} \\
a_{21}^{*} & a_{22}^{*}
\end{array}\right]+} \\
& +\left[\begin{array}{ll}
b_{11}^{*} & b_{12}^{*} \\
b_{21}^{*} & b_{22}^{*}
\end{array}\right]^{\prime}\left[\begin{array}{ll}
h_{11, t-1} & h_{12, t-1} \\
h_{21, t-1} & h_{22, t-1}
\end{array}\right]^{\prime}\left[\begin{array}{ll}
b_{11}^{*} & b_{12}^{*} \\
b_{21}^{*} & b_{22}^{*}
\end{array}\right],
\end{aligned}
$$

where: $h_{11, t}$ denotes the conditional variance of the stock market, $h_{12, t}$ the covariance of stock and foreign exchange markets, and $h_{22, t}$ the conditional variance of the foreign exchange market. The significance of the diagonal coefficients $a_{11, t}\left(a_{22, t}\right)$ suggests that the current conditional variance 
of $h_{11, t}\left(h_{22, t}\right)$ is correlated with its own past squared errors, while the significance of the lagged variance $b_{11, t}\left(b_{22, t}\right)$ indicates that the current conditional variance of $h_{11, t}\left(h_{22, t}\right)$ is affected by its own past conditional variance. Similarly, the significance of the off-diagonal coefficients $a_{12, t}$ and $b_{12, t}$ indicates evidence of shock and volatility transmission effects from the stock market to the foreign exchange market, whereas the significance of the off-diagonal coefficients $a_{21, t}$ and $b_{21, t}$ shows evidence of volatility transmission effects from the foreign exchange market to the stock market. The parameter matrices are estimated using the expanded BEKK-MGARCH $(1,1)$ equation:

$$
\begin{aligned}
h_{11, t+1}=c_{11}^{2}+a_{11}^{2} \varepsilon_{1, t}^{2} & +2 a_{11} a_{12} \varepsilon_{1, t} \varepsilon_{2, t}+a_{21}^{2} \varepsilon_{2, t}^{2}+b_{11}^{2} h_{11, t}^{2}+2 b_{11} b_{12} h_{12, t}+b_{21}^{2} h_{22, t}, \\
h_{22, t+1}= & c_{12}^{2}+c_{22}^{2}+a_{12}^{2} \varepsilon_{1, t}^{2}+2 a_{12} a_{22} \varepsilon_{1, t} \varepsilon_{2, t}+a_{21}^{2} \varepsilon_{2, t}^{2}+ \\
& +b_{12}^{2} h_{11, t}^{2}+2 b_{12} b_{22} h_{12, t}+b_{22}^{2} h_{22, t} .
\end{aligned}
$$

Equations (4) and (5) show how shocks or volatility are transmitted between the stock market and foreign exchange market in Nigeria. The significance of the off-diagonal parameters is evidence of shock and volatility transmission between the two markets. The parameters are estimated using the maximum likelihood estimation method optimized with the Broyden, Fletcher, Goldfarb, and Shanno (BFGS) algorithm. The conditional likelihood function $L(\theta)$ is expressed thus:

$$
L(\theta)=-T \ln (2 \pi)-\frac{1}{2} \sum_{t=1}^{T}\left(\ln \left|h_{t}\right|+\varepsilon_{t}^{\prime} H_{t}^{-1} \varepsilon_{t}\right),
$$

where: $T$ is the number of observations and $\theta$ is the parameter vector to be estimated.

The robustness of the multi-variate GARCH models can be evaluated using a number of diagnostics tests. The Ljung-Box (1978) $Q$ test statistics will be used to examine the null hypothesis of no autocorrelation in the estimated residuals and squared standardized residuals up to a specific lag. Also, Engle's (1982) LM statistic will be used to test the null hypothesis of no remaining ARCH effects up to a specific order. In fact, if the multi-variate GARCH model is specified correctly, then the estimated standardized residuals should behave like white noise, i.e., they should not display serial correlation, $\mathrm{ARCH}$ effect, or any other type of non-linear dependence.

\subsection{Data for analysis}

The dataset used in this study comprises the monthly All-share index (ASI) of the Nigerian Stock Exchange (NSE) and the average bureau de change (BDC) Naira/USD exchange rate for the period January 1996 to March 2013, totalling 207 observations for each variable. This time period was chosen to capture the effect of internationalisation of the NSE in 1995 and other fundamental changes made to regulate, and implement advanced technology for the operation of the Nigerian stock market ${ }^{8}$ as well as the current events. The choice of the BDC exchange rate has been motivated by the fact that it mirrors the market exchange rate during the era of dual exchange rate regime, which caused wide variation between official exchange rate and the

The NSE became internationalized in 1995 with the abrogation of the Exchange Control Act of 1962 and the Nigerian Enterprises Promotion Decree of 1989. These two laws constrained foreign participation in the Nigerian capital market. Consequent on their abrogation, foreigners now participate in the market both as operators and investors. Also, in line with global developments, the NSE changed from Call-over system of trading to Automated Trading System (ATS) in 1998. 
inter-bank exchange rate in Nigeria ${ }^{9}$. The BDC exchange rate series were collected from the Central Bank of Nigeria (CBN) statistics databank and transformed to change in exchange rate by taking first difference. The ASI was obtained from the NSE and converted into monthly returns as follows:

$$
R_{t}=\operatorname{Ln}\left(P_{t} / P_{t-1}\right) \times 100,
$$

where: $R_{t}$ is the daily returns, $P_{t}$ is closing ASI for Month $t, P_{t-1}$ is the previous month closing ASI, and Ln is natural logarithm. While change in BDC exchange rate serves as a proxy for the foreign exchange market, the ASI returns serve as the proxy for the stock market.

\section{EMPIRICAL RESULTS}

\subsection{Descriptive Statistics}

Figure 1, shows time series plots of log-level and monthly returns of the ASI as well as the monthly exchange rates and change in exchange rates from January 1996 to March 2013. The level of that ASI shows upward trend from 24794.4 points in February 2004 till when it peaked at 65652.38 points on February 2008 before falling 19851.89 points on March 2009 . The Naira( $(\mathbb{N}) / U S D$ exchange rate, on the other hand, started appreciating from $N 142.3 / U S D 1$ in May 2006 to $\mathrm{N} 118.7 / \mathrm{USD} 1$ in June 2008 before depreciating to $\mathrm{N} 180.6 / \mathrm{USD} 1$ by May 2009, and then started moving towards the average. The very high volatility during the global financial crises is obvious in both series, though in different directions and other high and low volatility can be seen. Figure 1 also displays the mean reversion tendency of stock returns and change in exchange rates. Figure 2 shows the estimated volatility of the stock and the foreign exchange markets as well as as their correlation.

\section{Figure 1}

Time Plot of NSE all-share index vs Naira/USD Exchange rate - January 1996 to March 2013
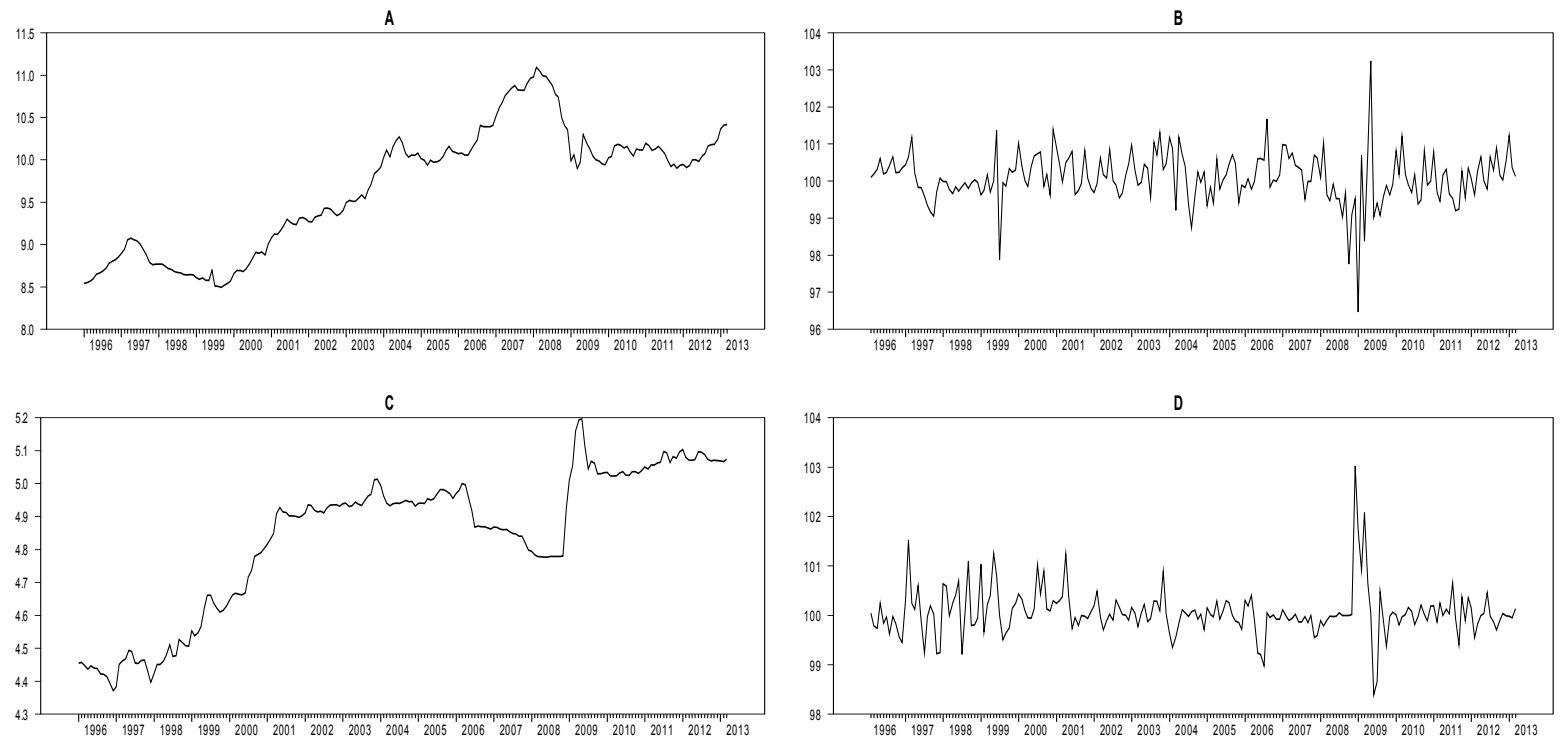

Notes: A - denotes the log-level of the NSE monthly All-share index; B - denotes the NSE monthly market returns; C - denotes the log-level of the Naira(N)/USD exchange rate; $\mathrm{D}$ - denotes the change in the Naira(N)/USD exchange rates.

Source: Author's own work.

The dual exchange rate regime was in effect from May 1993 to December 1998. On May 1993, for example, the official exchange rate (DAS) in Nigeria was $¥ 22.00 / U S D 1$ but was exchanged for $¥ 33.35 / U S D 1$ at the BDC. By May 1997, the DAS was still $N 22.00 / U S D 1$ but the BDC exchange rate was $\mathrm{N} 89.53 / \mathrm{USD} 1$. In January 1999 , the DAS flew to $\mathrm{N} 86.00 / \$ 1$ from $\mathrm{N} 22.00 / \mathrm{USD} 1$ in December 1998 . During these periods however, the $\mathrm{BDC}$ was consistent in mirroring the market rate. 
Figure 2

Estimated volatility and correlation of the stock and foreign exchange markets in Nigeria
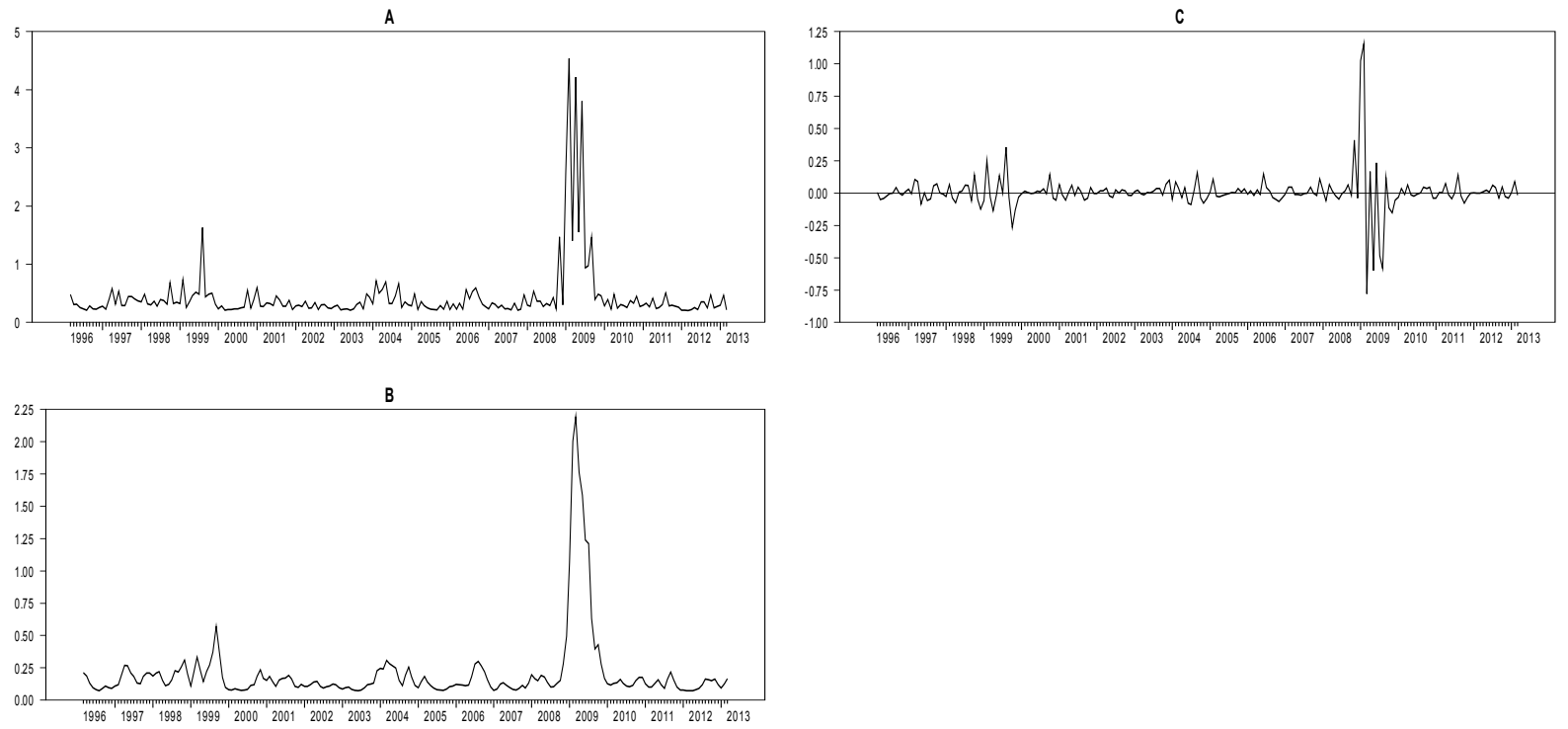

Notes: A - denotes the estimated volatility of the stock market; B - denotes the estimated volatility of the foreign exchange market; C - shows the correlation between the volatilities of the stock and foreign exchange markets

Source: Author's own work.

Descriptive statistics and ARCH-LM estimates are presented in Table 1. As shown in Table 1, the monthly mean stock return is $0.91 \%$ and the standard deviation is 6.7 . The mean exchange rate for the study period is $\mathrm{N} 129.04 / \mathrm{USD} 1$ and the standard deviation is 25.93 . The stock returns exhibit negative skewness and changes in the exchange rate show positive skewness, suggesting that there are more negative (positive) observations in the stock returns (change in exchange rate) than in standard normal distribution. The kurtosis of a normal distribution is 3 . But the excess kurtosis for the stock return is 6.94 and change in exchange rate is 9.61 , indicating that both series are more peaked than the normal distribution. Finally, the Jarque-Bera test results are significant at conventional levels, suggesting that normality assumptions for all the series are doubtful. Notice also from Table 1 that ARCH-LM, Ljung-Box Q and McLeod-Li tests all reject the null hypotheses of no ARCH effect, no serial correlation in returns and squared returns at the $1 \%$ significance level. These results are in favour of a model that incorporates ARCH/GARCH features.

Table 1

Descriptive statistics and test for ARCH effect

\begin{tabular}{|c|c|c|c|c|c|c|c|c|}
\hline & Mean & S.D & Skew. & E.Kurt & JB Stat & LM (6) & $\operatorname{McL}(28)$ & $\mathrm{Q}(28)$ \\
\hline EX.rate & 129.04 & 25.93 & $\begin{array}{l}-0.463 \\
(0.00)\end{array}$ & $\begin{array}{l}-0.901 \\
(0.00)\end{array}$ & $\begin{array}{c}14.425 \\
(0.00)\end{array}$ & $\begin{array}{l}49.38 \\
(0.00)\end{array}$ & $\begin{array}{c}4072.72 \\
(0.00)\end{array}$ & $\begin{array}{c}4356.6 \\
(0.00)\end{array}$ \\
\hline ChEXrate & 0.300 & 2.323 & $\begin{array}{l}1.555 \\
(0.00)\end{array}$ & $\begin{array}{l}9.616 \\
(0.00)\end{array}$ & $\begin{array}{c}876.72 \\
(0.00)\end{array}$ & $\begin{array}{l}31.62 \\
(0.00)\end{array}$ & $\begin{array}{c}131.45 \\
(0.00)\end{array}$ & $\begin{array}{l}69.30 \\
(0.00)\end{array}$ \\
\hline Rt & 0.910 & 6.708 & $\begin{array}{l}-0.642 \\
(0.00)\end{array}$ & $\begin{array}{l}6.942 \\
(0.00)\end{array}$ & $\begin{array}{c}427.91 \\
(0.00)\end{array}$ & $\begin{array}{l}35.45 \\
(0.00)\end{array}$ & $\begin{array}{l}55.51 \\
(0.00)\end{array}$ & $\begin{array}{l}59.26 \\
(0.00)\end{array}$ \\
\hline
\end{tabular}

Note: $P$-values are displayed as (.). The ARCH LM tests are conducted under null hypothesis of no ARCH effect and at $95 \%$ confidence level using squared returns. The Ljung-Box statistic, $Q$ (28), checks for the serial correlation of the returns up to the 28th order and McL (28) checks for the serial correlation of the squared returns up to the 28 th order.

Source: Author's calculation. 


\subsection{Unit Root Test Results}

Before the multi-variate GARCH (1.1) model is estimated, it is necessary to check the stationarity of the variables. This step is to ensure that the series are stationary because estimates obtained from non-stationary series are not reliable. Table 2 shows the results of the augmented Dickey-Fuller (ADF) unit root test and Kwiatkowski (KPSS) stationarity test for the level series and their returns. The null hypothesis of the ADF test is that a time series contains a unit root, whereas the null hypothesis of the KPSS test is that a time series is stationary. As shown in Table 2, the calculated values of the ADF test statistics indicate that the level series contain a unit root at the $1 \%$ significance level, implying that the level series are non-stationary. However, in the case of the return series, the statistics reject the null hypothesis of a unit root at the $1 \%$ significance level, implying that the returns are stationary for the two series. The results of the KPSS tests, on the other hand, show that the level series are non-stationary, whereas, their first differences are stationary.

Table 2

Unit root tests results

\begin{tabular}{|c|c|c|c|c|}
\hline \multirow[b]{3}{*}{ Variables: } & \multicolumn{4}{|c|}{ ADF } \\
\hline & \multicolumn{2}{|c|}{ Level } & \multicolumn{2}{|c|}{ First Difference } \\
\hline & critical value $5 \%$ & computed value & critical value $5 \%$ & computed value \\
\hline EXrate & -3.432 & -2.727 & -3.432 & $-8.619^{*}$ \\
\hline \multirow[t]{3}{*}{ Rt } & -3.432 & -1.866 & -3.432 & $-6.272^{*}$ \\
\hline & \multicolumn{4}{|c|}{ KPSS } \\
\hline & \multicolumn{2}{|c|}{ Level } & \multicolumn{2}{|c|}{ First Difference } \\
\hline Variables: & critical value $5 \%$ & computed value & critical value $5 \%$ & computed value \\
\hline EXrate & 0.4630 & $3.1169^{*}$ & 0.4630 & 0.1027 \\
\hline Rt & 0.4630 & $3.3403^{*}$ & 0.4630 & 0.1413 \\
\hline
\end{tabular}

Note: ADF and KPSS lag lengths are selected using Akaike information criterion (AIC). ${ }^{*}$ indicates significant at $99 \%$ confidence level. Source: Author's calculation.

\subsection{Covariance/Correlation Matrix Estimates}

Table 3 displays the covariance/correlation matrix between squared stock and foreign exchange markets returns. The covariance matrix is a measure of the extent to which two variables tend to move together. Notice from the entry on the diagonal of the covariance matrix in row 2 column 1 that the covariance of the foreign exchange market with stock market is large and positive, suggesting variance relationship between foreign exchange and stock markets. On the other hand, the covariance of the stock market with the foreign exchange market is approximately zero, suggesting that variance of both markets tends to be unrelated. In addition, the correlation between the stock and foreign exchange markets is very weak, suggesting that the markets have weak mean association. 
Table 3

Covariance and correlation matrices

\begin{tabular}{|c|c|c|}
\hline & \multicolumn{2}{|c|}{ Covariance Matrix } \\
\hline & $\Delta$ Exrate & $\mathrm{Rt}^{2}$ \\
\hline$\Delta$ Exrate & 382.798 & 0.281 \\
\hline \multirow[t]{3}{*}{$\mathrm{Rt}^{2}$} & 759.932 & 19077.890 \\
\hline & \multicolumn{2}{|c|}{ Correlation Matrix } \\
\hline & $\Delta$ Exrate & $\mathrm{Rt}^{2}$ \\
\hline$\Delta$ Exrate & 1 & 0.20850 \\
\hline $\mathrm{Rt}^{2}$ & 0.20850 & 1 \\
\hline
\end{tabular}

Source: Author's calculation.

\subsection{MGARCH (1,1)-BEKK Results}

The results of the multi-variate GARCH (1.1)-BEKK model employed to investigate the nature of volatility transmission between the stock and the foreign exchange markets are shown in Table 4. Notice from Table 4 that the estimates of the diagonal parameters, $A_{22}$ and $B_{11}, B_{22}$, are all statistically significant at $99 \%$ confidence level. This indicates that a strong GARCH (1.1) process drives the conditional variances of the markets returns. In other words, own past volatility affect the current volatility of the stock and foreign exchange markets in Nigeria. However, $A_{11}$ is not significant, suggesting that a past shocks do not influence volatility in the stock market.

The off-diagonal elements of matrices $A$ and $B$ capture cross-market shock and volatility transmission between the markets. From the off-diagonal elements of matrix $A$, we see evidence of bi-directional shock transmissions between the stock market and foreign exchange market at $1 \%$ significance level. This suggests that information flow in the foreign exchange market also impacts the stock market. In the same way, shocks in the stock market affect the foreign exchange market. Evidence of bi-directional shock transmission between stock and foreign exchange markets are not surprising given advances in information and communication technology (ICT) in the Nigerian financial markets. It is thus very easy for information to flow between the two markets. This finding provides new insight into the interaction of volatility shocks among stock and foreign exchange markets in Nigeria.

The results of the off-diagonal elements of matrix $B$, however, show evidence of a unidirectional volatility transmission from the foreign exchange market to the stock market, as only the off-diagonal parameter $B_{21}$ is statistically significant at the $99 \%$ confidence level. The results agree with the findings of Federova and Salem (2010) who find uni-directional volatility spillovers from foreign exchange to stock markets in Eastern European markets and Russia. The results are also consistent with the study of Okpara and Odionye (2012), which provide evidence, using univariate EGARCH model, for a unidirectional volatility spillover running from exchange rate to stock prices in Nigeria. Hoon and Yoon (2013) also find evidence of uni-directional volatility spillover effect from the foreign exchange market to the stock market in the post-crisis sample period of their study in Korea.

The uni-directional volatility transmission from foreign exchange market to stock market in Nigeria may partly be in response to the import-dependent and mono-production nature of the economy. As highlighted in section one, the majority of the goods and services consumed in Nigeria are imported from different parts of the world and the major currency of importation is the USD. 
Table 4

Estimated results of the GARCH-BEKK model

\begin{tabular}{cccc}
\hline \hline Parameters & Coefficients & $t$-statistic & $P$-value \\
\hline $\boldsymbol{C}_{\mathbf{( 1 , 1 )}}$ & 3.2802 & 4.3194 & 0.0000 \\
$\boldsymbol{C}_{(\mathbf{2}, \mathbf{1})}$ & 0.2227 & 0.8000 & 0.4236 \\
$\boldsymbol{C}_{(\mathbf{2}, \mathbf{2})}$ & 0.2863 & 0.7699 & 0.4413 \\
$\boldsymbol{A}_{(\mathbf{1}, \mathbf{1})}$ & 0.1403 & 1.4241 & 0.1544 \\
$\boldsymbol{A}_{(\mathbf{1 , 2})}$ & 0.1164 & 6.2767 & 0.0000 \\
$\boldsymbol{A}_{(\mathbf{2}, \mathbf{1})}$ & -1.133 & -3.237 & 0.0012 \\
$\boldsymbol{A}_{(\mathbf{2}, \mathbf{2})}$ & 0.6253 & 3.6424 & 0.0002 \\
$\boldsymbol{B}_{(\mathbf{1}, \mathbf{1})}$ & 0.7447 & 6.2064 & 0.0000 \\
$\boldsymbol{B}_{(\mathbf{1}, \mathbf{2})}$ & -0.042 & -0.987 & 0.3236 \\
$\boldsymbol{B}_{(\mathbf{2}, \mathbf{1})}$ & 0.5030 & 2.6152 & 0.0089 \\
$\boldsymbol{B}_{(\mathbf{2}, \mathbf{2})}$ & 0.7503 & 9.9004 & 0.0000 \\
\hline
\end{tabular}

Panel B: Diagnostic Tests

\begin{tabular}{lcc}
\hline & Statistic & Signif. Lvl. \\
\hline $\boldsymbol{Q}_{\boldsymbol{i}} \mathbf{( 1 2 )}$ & 13.491 & 0.334 \\
$\boldsymbol{Q}_{\boldsymbol{i}}^{\mathbf{2}} \mathbf{( 1 2 )}$ & 11.536 & 0.483 \\
$\boldsymbol{Q}_{\boldsymbol{j}}(\mathbf{1 2})$ & 9.852 & 0.628 \\
$\boldsymbol{Q}_{j}^{\mathbf{2}} \mathbf{( 1 2 )}$ & 4.850 & 0.962 \\
$\mathbf{M V ~ L M ~}\{\mathbf{1 2}\}$ & 1.710 & 0.999 \\
$\mathbf{M V} \boldsymbol{Q}(\mathbf{1 2})$ & 11.145 & 0.516 \\
\hline \hline
\end{tabular}

Note: $\mathrm{Q}_{i}$ and $\mathrm{Q}_{j}$ are the Ljung-Box Q-statistic for the stock market and foreign exchange market respectively. MV LM and Q are multi-variate ARCH-LM and Ljung-Box Q-statistic for null hypotheses of no ARCH effect and no autocorrelation in multi-variate GARCH model. Lag length is displayed as (.) and degrees of freedom is shown $\{$.$\} . All the tests are conducted at 5\% significance levels.$

Source: Author's calculation.

The importers and other peeople who make payment for one form of international transactions or the other, such as payment of school fee abroad, bid for USD through the BDCs. This creates demand pressure on the USD. Similarly, transactions in the major export product of Nigeria, crude oil, are internationally priced in USD thereby making this currency one of the major policy variables in the Nigerian economy. These factors, amongst others, may explain the uni-directional volatility transmission from the foreign exchange market to the stock market, which normally should serve as the 'engine' for generating USD.

One of the major economic implications of the shock and volatility linkages between the stock and the foreign exchange markets for the investors, portfolio managers and financial market regulators is the need to dissect any information from both markets. Equity investors and managers need to monitor exchange rate movement because it may have great impact on the risk and cost of capital on the stock market. Similarly, foreign exchange dealers may also need to be mindful of developments in the stock market, as shocks from the stock market impact the foreign exchange market. Financial market regulators, on their part, should intensify efforts at diversifying the production base of the Nigerian economy. This will not only reduce the importinduced demand pressure on the USD but will also increase activities on the stock market as more companies become listed on the NSE. In addition, the government should direct policy efforts at attracting foreign investments which will establish companies that will domestically produce most of the goods presently imported by Nigeria. 
The results of diagnostic tests conducted to ascertain robustness of the estimated model are displayed on panel $B$ of Table 5. From panel $B$, notice that the Ljung-Box Q-statistic for both the residuals and squared residuals of stock and foreign exchange markets are not significant, suggesting that there is no correlation in the residuals. Similarly, the mult-ivariate ARCH-LM and Ljung-Box results indicate that the null hypotheses of no ARCH effect and no serial correlation are accepted at $1 \%$ significance level. Hence, there appear to be no specification error; the model is therefore robust for policy analysis.

\section{CONCLUDING REMARKS}

Volatility transmission between stock and foreign exchange markets is of particular interest to academics, foreign exchange traders, professional investors and financial market regulators due to the importance of the markets in portfolio and risk management as well as channels of monetary policy. Given such important roles for the markets, this study evaluates volatility transmission between stock and foreign exchange markets in Nigeria using sample period ranging from January 1996 and ending with March 2013.

The results of the multi-variate GARCH (1.1)-BEKK model show evidence of volatility clustering in both stock and foreign exchange markets as evident in the significance of the GARCH coefficient for each of the markets. The results also show bi-directional shock transmissions between the stock market and foreign exchange market, suggesting that information flow in the foreign exchange market impacts the stock market and vice versa. Finally, the results show evidence of a uni-directional volatility transmission from the foreign exchange market to the stock market, as only the off-diagonal parameter $\mathrm{B}_{21}$ is statistically significant.

Hence, investors in the stock and/or foreign exchange markets in Nigeria should vigilantly monitor and dissect all information within the two markets as part of their investment strategy.

\section{References}

Arifin J., Syahruddin N. (2011) Volatility Spillovers between Equity and Currency Markets in ASEAN-5 Countries during Crises, Proceedings of $13^{\text {th }}$ International Conference on Banking and Finance: Lessons Learned from the Financial Crises, 12-13 October, Ostrava Czech Republic. www.opf.slu.cz/kfi/icfb/proc2011/pdf/02_ Arifin.pdf

Baba Y., Engle R.F., Kraft D.F., Kroner K.F. (1990) Multivariate Simultaneous Generalized ARCH, Mimeo, Department of Economics, University of California, San Diego. http://econ.arizona.edu/docs/Working_ Papers/Archives/1992/WP_92-5.pdf

Bhar R., Hamori S. (2003) New Evidence of Linkages among G-7 Stock Markets, Finance Letters, 1, 35-40. http:// papers.ssrn.com/sol3/papers.cfm?abstract_id=412591

Bollerslev, T. (1986), A Generalized Autoregressive Conditional Heteroscedasticity, Journal of Econometrics, 31, pp. 307-327. http://dx.doi.org/10.1016/0304-4076(86)90063-1

Bollerslev T. (1990) Modelling the Coherence in Short-run Nominal Exchange Rates: A Multivariate Generalized ARCH Model, Review of Economics and Statistics, 72 (3), pp. 498-505. http://www.jstor.org/stable/2109358

Bollerslev T., Engle R.F., Wooldridge J.M. (1988) A Capital Asset Pricing Model with Time-varying Covariances, Journal of Political Economy, 96 (1), pp. 116-131. http://www.jstor.org/stable/1830713

Branson W. (1983) Macroeconomic Determinants of Real Exchange Rate Risk, in: R. Herring (Ed.), Managing Foreign Exchange Risk, MA: Cambridge University Press.

Branson W.H., Henderson D.W. (1985) The Specification and Influence of Assets Markets. In Handbook of International Economics, 2, Edited by R.W. Jones, P.B. Kenen, Amsterdam (Elsevier), pp. 749-805.

Choi D.F., Tian V., Fu F.Y. (2009) Volatility Spillovers between New Zealand Stock Market Returns and Exchange Rate Changes before and after the 1997 Asian Financial Crisis, Asian Journal of Finance \& Accounting, 1 (2), pp. 106-117. http://hdl.handle.net/10536/DRO/DU:30042539 
Dornbusch R., Fischer S. (1980) Exchange Rates and the Current Account, American Economic Review, 12, pp. 7-12. http://www.jstor.org/stable/1805775

Emenike K.O. (2010) Modelling Stock Returns Volatility in Nigeria Using GARCH Models, African Journal of Management and Administration, 3 (1), pp. 8-15. http://mpra.ub.uni-muenchen.de/23432/

Engle R.F. (1982) Autoregressive Conditional Heteroscedasticity with Estimates of the Variance of the United Kingdom Inflation, Econometrica, 50, pp. 987-1008. http://www.jstor.org/stable/1912773

Engle R.F., Ito T., Lin W.L. (1990) Meteor Showers or Heat Waves? Heteroskedastic Intra-daily Volatility in the Foreign Exchange Market, Econometrica, 58 (3), pp. 525-542. http://www.jstor.org/stable/2938189

Engle R.F., Kroner K.F. (1995) Multivariate Simultaneous Generalized ARCH, Econometric Theory, 11, pp. $122-150$. http://www.jstor.org/stable/3532933

Fedorova E., Saleem K. (2010) Volatility Spillovers between Stock and Currency Markets: Evidence from Emerging Eastern Europe, Journal of Economics and Finance, 60 (6), pp. 519-533. http://journal.fsv.cuni.cz/ storage/1199_str_519_533_-_fedorova.pdf

Felipe S.P., Diranzo C.F. (2006), Volatility Transmission Models: A Survey, Revistade Economia Financiera, pp. $32-81$. Available online at: http://papers.ssrn.com/soL3/papers.cfm?abstract_id=929953

Frankel J. (1983) Monetary and Portfolio Balance Models of Exchange Rate Determination, in: J. Bhandari, B.Putman (Eds), Economic Interdependence and Flexible Exchange Rates, MA, MIT Press.

Ghosh S. (2012), Volatility Spillover in the Foreign Exchange Market: The Indian experience, Kiel Advanced Studies Working Papers, No. 460. http://www.ifw-kiel.de/ausbildung/asp/asp-wp/2012/TP2\%20Ghosh.pdf

Hamao Y., Masulis R.W, Ng V. (1990) Correlations in Price Changes and Volatility across International Stock Markets, Review of Financial Studies, 3 (2), pp. 281-307. DOI: 10.1093/rfs/3.2.281

Kang H.S., Yoon S. (2012) Spillover Effects between Exchange Rate and Stock Price in Asian Emerging Markets, The Korean Journal of Financial Engineering, 11, pp. 147-165. http://www.kafe.or.kr/paper/include/download. php? name $=1340943430.0993 \&$ key $=\&$ dir $=$ PAPER\&subtype $=\&$ viewname $=07 \%$ B0 $\% A D \% B B \% F 3 \% C 8 \% C$ $6 \% \mathrm{C} 0 \% \mathrm{~B} 1 \% \mathrm{BC} \% \mathrm{BA} \% \mathrm{~B} 9 \% \mathrm{CE} . \mathrm{pdf}$

Kang H.S., Yoon S. (2013) Revisited Return and Volatility Spillover Effect in Korea, Korea and the World Economy, 14 (1), pp. 121-145. http://www.akes.or.kr/akes/downfile/14.1.5.\%20Kang_Yoon.pdf

Hong Y. (2001) A Test for Volatility Spillover with Application to Exchange Rates, Journal of Econometrics, 103, pp. 183-224. http://dx.doi.org/10.1016/S0304-4076(01)00043-4

Hurditt P. (2004) An Assessment of Volatility Transmission in the Jamaican Financial System, Journal of Business, Finance and Economics in Emerging Economies, pp. 1(1), 1-28. http://www.ccmf-uwi.org/files/publications/ journal/2006_1_1/1_28.pdf

Inagaki K. (2007) Testing for Volatility Spillover between the British Pound and the Euro, Research in International Business and Finance, 21, pp. 161-174. http://dx.doi.org/10.1016/j.ribaf.2006.03.006

Kanas, A. (2000), Volatility Spillover between Stock Returns and Exchange Rate Changes: International Evidence, Journal of Business Finance \& Accounting, 27 (3\&4), 447-467. DOI: 10.1111/1468-5957.00320.

Karolyi, G. A. (1995), A multivariate GARCH Model of International Transmissions of Stock Returns and Volatility: The Case of the United States and Canada, Journal of Business and Economic Statistics, 13 (1), 11-25. http:// www.jstor.org/stable/1392517

Kim K. (2003) Dollar Exchange Rate and Stock Price: Evidence from Multivariate Cointegration and Error Correction Model, Review of Financial Economics, 12, pp. 301-313. http://dx.doi.org/10.1016/S1058-3300(03)00026-0

Ljung G.M., Box G.E.P. (1978) “On a Measure of Lack of Fit in Time Series Models”, Biometrika, 67, pp. $279-303$. DOI: 10.1093/biomet/65.2.297

Malik F., Ewing B.T. (2009) Volatility Transmission between Oil Prices and Equity Sector Returns, International Review of Financial Analysis, 18, pp. 95-100. http://dx.doi.org/10.1016/j.irfa.2009.03.003

Mishra A.K., Swain N., Malhotra D.K. (2007) Volatility Spillover between Stock and Foreign Exchange Markets: Indian Evidence, International Journal of Business, 12(3), pp. 343-359. http://www.ibrarian.net/navon/page. jsp?paperid $=17798268$

Morales L., O’Donnell M. (2007) Volatility Spillovers between Exchange Rates and Equity Markets: Evidence from Spain, Portugal and Italy, Conference papers (6). http://arrow.dit.ie/buschaccon/6

Nelson D. (1991) Conditional Heteroscedasticity in Asset Returns: A New Approach, Econometrica, 59 (2), pp. 347-370. http://www.jstor.org/stable/2938260

Nnachi A. (2008), Financial Linkages of the Nigerian Stock Market, Unpublished PhD Thesis Submitted to the Department of Banking and Finance, University of Nigeria Nsukka.

Okpara G.C., Odionye J.C. (2012) The Direction of Volatility Spillover between Stock Prices and Exchange Rate: Evidence from Nigeria, Elixir Finance Management, 42, pp. 6410-6414. http://www.elixirpublishers.com/ articles/1350724501_42\%20\%282012\%29\%206410-6414.pdf 
Turkyilmaz S., Balibey M. (2013) The Relationship among Interest Rate, Exchange Rate and Stock Prices: A BEKKMGARCH Approach, International Journal of Economics, Finance and Management Sciences, 1(3), pp. 166-174. DOI: 10.11648/j.ijefm.20130103.16.

Yang S., Doong S. (2004) Price and Volatility Spillovers between Stock Prices and Exchange Rates: Empirical Evidence from the G-7 Countries. International Journal of Business and Economics, 3(2), pp. 139-153. http://www.ijbe.org/table\%20of\%20content/pdf/vol3-2/vol3-2-04.pdf

Yaya O.S., Shittu O.I. (2010), on the Impact of Inflation and Exchange Rate on Conditional Stock Market Volatility: A Reassessment, American Journal of Scientific and Industrial Research, 1 (2), pp. 115-117. DOI:10.5251/ ajsir.2010.1.2.115.117 